essential is the study and investigation of basic problems. Success of armies in the field is dependent on careful planning and preparation at headquarters, and victories in the war against disease can only be achieved by due application and increased knowledge of the fundamential medical sciences". No better dedication of a gift could be written and no kotter purpose could be served than to encourage the patient labours of those who lay surely the foundations on which others build. It is significant too that the donor expresses the hope that "the gifts will enable the Council to proceed with confidence with thoir responsible task and to engage the services of men of outstanding ability to assist them in their labours". In the post-war world of medicine in Great Britain the College will indeed have a unique place. Apart from its primary task of testing the fitness of those who aspire to practise the art and advance the service of surgery, it will have a special function in providing a link ketween the laboratory sciences and the treatment of the sick. Perhaps, too, in the future it will aspire to develop a hospital where discoveries at the laboratory bench will become quickly the triumphs of the hospital ward, and where the perplexing problems of disease will be brought rapidly to the attention of the laboratory worker. Cross-fertilization of ideas between laboratory and ward has already, in the association of the Rockefeller Hospital with the Rockefeller Institute in New York, produced advances in the science of medicine which have been of lasting benefit to suffering humanity.

Mr. Collins has been for many years a generous benefactor to hospitals in Great Britain, but his latest gift, far from benefiting but a few hospitals, will help to provide that new knowledge which is the free gift of medical research to all mankind.

\section{Preservation of Museums in Italy}

Reprying to questions in the House of Commons, Sir James Grigg, Secretary of State for War, stated. that an adviser is being appointed to deal with archxological questions such as measures for the protection and conservation of ancient monuments and works of art in countries occupied by British troops. Meanwhile British and American experts are already in occupied territory engaged in the supervision and protection of ancient monuments, museums, etc. The British officers sent or provisionally selected are from the British Museum, Inspectorate of Ancient Monuments (Ministry of. Works), National Gallery and the Royal Institute of British Architects. Lists of æesthetic and aneient monuments have been prepared in Great Britain, and detailed instructions supplied to these officers regarding closing, guarding and, where necessury, repairing museums and similar institutions. Italian curators and their stafls, where suitable, are to be retained. In this connexion it is interesting to read Dr. G. B. Bidder's letter in The T'imes of October 14, in which he states that the aquarium in the Villa Nazionale of Naples, and so presumably the famous Stazione Zoologica Internazionale, is safe. Dr. Bidder adds that so lately as last August, the director, Dr. Reinhard Dohrn, was still in charge of the Station.

\section{Anthropological Aspects of the Origins of War}

A sTUDY of the origin of war and its various manifestations from an anthropological point of view, by J. R. Swanton, of the Bureau of American Ethnology, which has been issued by the Smithsonian Institution in the War Background Studies series (No. 12), indicates the impossibility of separating the consideration of wars between tribes or nations from disturbances internal to them. Reviewing the various motives which lead to war and comparing warfare in simple and in advanced societies, Mr. Swanton emphasizes the relations between motives governing the individual and those which result in collective hostilities. These and further considerations of group controls, international relations, the effect of warfare upon trade and the place of the military establishment in the national life, lead to the conclusion that war is an expression of man's antisocial tendencies; and just as individual and collective crimes have to be controlled within the State by men trained and equipped to meet them, so the destructive threat represented by foreign armed forces when used for aggression must be countered by armed forces prepared to meet them. Between many nations there is a constantly increasing tendency to settle differences by peaceful means, and if these areas of law and of good feeling continue to spread, the preservation of order will pass more and more to the police, or to armed forces acting in that capacity. Consideration of the origins of war and attitudes towards it among different people shows that collective pugnacity is an acquired traitcultural not biological. Fear and not hatred is the underlying if not the dominant motive, and when this fear can be allayed, belligereney will disappear with it. There is no mystery about the force required to terminate warfare. All that is needed is the will to do so.

\section{A National Administrative Staff College}

A sHort statement, "A National Administrative Staff College", has recently been issued as a contribu tion to discussion by the members of a group which during the past twelve months has bcen studying this topic (honorary secretary, N.A.S.C., Norwich House, Southampton Place, London, W.C.1). The proposal is to found such a College to investigate and to expand the technique of organization and administration in civil life. To it will be admitted men and women aged about 28-34 who have shown ability and capacity in their particular spheres, including not only Civil servants, but also local government officers, men from industry and commerce, trade union officials and members of trade associations and professions such as medicine, the law, the church and education. In addition to training such executives, the College will aim at promoting a better understanding of the inter-relation of the activities of the organizations from which its students are drawn, and it should also provide a centre for resenrch into all aspects of administration. The curriculum will include a close study of the fundamental principles on which sound administration must be based, and an introduction to the many disciplines of which students must make use in their subsequent work. The whole course will emphasize the responsibility of leadership and the importance of correct practice in dealing with the central issue of human relations. The College will also endeavour to nourish the other qualities required in a leader-moral courage, judgment, energy, imagination. Probably not more than a quarter of the time will be devoted to formal instruction, and the fullest use will be made of modern methods such as the 'case' method. Fees per student 
would be about $£ 30$ per month, including living expenses and tuition. The group has already in draft a memorandum and articles of association, and is prepared to incorporate the College and to form an initial court of governors.

\section{Eratosthenes and the Circumference of the Earth}

In Sky and Telescope of September, under the heading "Saluting an Astronomer", Joseph R. Habes has an article which describes the method adopted by Eratosthenes for measuring the circumference of the earth. He knew that the sun threw no shadow at the summer solstice at Syene (the modern Assuan) and at the same hour at Alexandria the pointers of the sundials threw shadows, because Alexandria is north of Syene. He found that the arc of the shadow in the hemispherical bowl of the sundial was 1/50 of its circle, and hence concluded that the arc of the earth between Syene and Alexandria, which was 5,000 stadia, was $1 / 50$ of the great circle of the earth. By this means he found that the circumference of the earth was 250,000 stadia, according to Cleomedes, but Strabo says that it was 252,000 stadia. A discrepancy arises when we come to consider the length of the stadium. The Greek stadium was $606 \cdot 75 \mathrm{ft}$., and if Eratosthenes used this he was obviously very much in error in his computation. On the other hand, Pliny in his "Naturalis Historia" claims that Eratosthenes made 40 stadia equal to the Egyptian schoinus, and if this be so, taking the schoinus as 12,000 royal cubits of 0.525 metres each, the length of the stadium was $516 \cdot 73 \mathrm{ft}$. If we accept the account of Strabo that Eratosthenes measured the circumference of the earth as 252,000 stadia, the circumference would be 24,662 miles, and the polar diameter 7,850 miles-only 50 miles short of the true polar diameter. This is considered to be one of the first great triumphs of scientific calculation.

\section{Association of Scientific Workers : Scientific Film Group}

$I_{N}$ view of the rapid increase in the applications of photography in science and industry, the West Midland Area of the Association of Scientific Workers has formed a Scientific Film Group. By means of lectures, exhibitions and news letters containing abstracts of recent publications, the Group will provide information for scientific workers using photographic techniques in industrial processes and research laboratories. The Group will also foster interest in the manifold applications of photography. It has already set up an information service able to provide expert advice on all aspects of photographic technique. The Group will endeavour to meet the demand of the general public for good-quality scientific films covering the whole field of science and technology. Monthly film shows will be held in Birmingham throughout this winter. The first show will take place in the middle of November. In the future the Group intends to produce original films and photographs. Applications for membership and inquiries should be addressed to Mr. H. Zerkowsky, Rowney Green, Nr. Alvechurch, Wores.

\section{Early Scientific Works}

Catalogue 8, recently published by Davis and Orioli of 1 St. Martin's Street, Wallingford, Berks, contains a collection of 143 items printed before 1500 . In addition to works on theology, philosophy and literature, heraldry and cookery, science and medieine are presented by the following works, among others : Albertus Magnus, "De secretis mulierum" (c. 1500); Aristotle, "De numero Partium" (c. 1490); Bartholomoeus Anglicus, "El libro de proprietatibus" (1494) ; Capillutus, "De curatione pestiferorum" (c. 1487) ; Celsus, "De medicina" (1497); Decembrius, "De Genitura Hominis" (c. 1495); Mesue's "Opera Omnia" (1497) ; Savonarola, "Practic in Medicina" (1498) and Silvaticus, "Opus Panectarum Medicinæ" (1498).

\section{Announcements}

DR. B. A. KeEN, assistant director at Rothamsted Experimental Station, will ke absent from Rothamsted for approximately twelve months, acting as a scientific adviser to the Middle East Supply Centre, Cairo. He will report on the scientific and technical problems and resources (including personnel) in the area, and make recommendations on the establishment of a suitable organization, in the Middle East and elsewhere, to ensure the fullest practicable service of information and advice, with special reference to the post-war period. Dr. Keen will deal with agricultural resources and development and related problems, including education. He will be accompanied by Dr. E. B. Worthington, who will examine various non-agricultural matters. An American representative is expected to join the mission at a later date. The countries to be visited extend from Persia to Libya and from Turkey to the Sudan. It is hoped that the mission will be able to report by November 1944.

THe following appointments and promotions in the Colonial Service have recently been made: P. S. Hammond, agrieuitural superintendent, Gold Coast; D. K. MeEwan Kevan, agricultural officer, Kenya; W. V. Rose, agricultural officer, Nyasaland; R. O. Williams, agricultural officer, Kenya ; H. B. Atkinson, inspector of plants and produce, Gold Coast; G. G. Robinson, entomologist, Medical Department, Northern Rhodesia; N. S. Stevenson (conservator of forests, British Honduras), conservator of forests, Nigeria.

THE following appointments in the University of Sheffield have recently been made: Dr. A. I. G. McLaughlin (H.M. medical inspector of factories), honorary lecturer in industrial medicine in the De. partment of Public Health; Mr. P. E. H. Howarth and Mr. R. E. Peasegood, temporary demonstrators in anatomy; Captain J. H. Hale, assistant bacteriologist and demonstrator in bacteriology; Dr. Enid Bankier, demonstrator in zoology to medical and dental students; Mr. W. Davies, research assistant in refractory materials (in addition to his duties as temporary part-time assistant lecturer in geology).

THE British Association of Refrigeration, at its forty-fourth annual meeting, has decided to change its title to the Institute of Refrigeration, the change to take place on March 26, 1944. At the same time, the Association will establish a qualified class of technical membership attainable by examination on the lines of the major engineering institutions.

R. J. BRAIDwood has issued as a reprint from the "1943 Britannica Book of the Year" notes describing recent archæological work in Iraq, Palestine, Kenya, Morocco, England, etc. The notes form an excellent and useful three-page summary of British war-time discoveries and publications in the realm of prehistory. 